\title{
EVALUATION OF INORGANIC AND ORGANIC NUTRIENT SOURCE IMPACTS IN NUTRIENT TMDLs ${ }^{1}$
}

\author{
Anne Jones-Lee, PhD and G. Fred Lee, PhD, PE, DEE \\ G. Fred Lee \& Associates \\ 27298 E. El Macero Drive \\ El Macero California 95618 \\ phone: (530)753-9630 - fax: (530) 753-9956 \\ email: gfredlee@aol.com - website: www.gfredlee.com
}

\begin{abstract}
There is a resurgence of interest in controlling the excessive fertilization(eutrophication) of surface waters in order to protect domestic water supplies and other beneficial uses of waters from impairment (pollution) by excessive growths of algae or other aquatic plants whose growth is stimulated by nitrogen and phosphorus. An area of particular concern is the nutrients added to waterbodies through the land application of inorganic fertilizers and management of domestic wastewater sludges (biosolids), animal manure, and compost that could lead to surface and ground water pollution. With the development of TMDLs to control excessive fertilization of waterbodies and the emphasis on protecting domestic water supply watersheds from pollution (source protection), the use of fertilizers as well as the regulation of the management of waste residues on land needs to be focused on controlling surface and ground water pollution. Those who fertilize lands as part of crop production as well those who dispose of waste residues (biosolids, animal manure, and compost) on land will be required as part of nutrient TMDLs to conduct comprehensive, reliable monitoring programs to ensure that the fertilizer nutrients and the constituents in the waste do not cause pollution - impairment of uses - of surface and ground waters associated with the waste management activities. The current federal and state regulatory agency guidance on management of biosolids needs to be amended to include a monitoring program to determine if nitrogen, phosphorus and, for that matter other constituents, in the biosolids cause surface or ground water pollution. It is important that the groundwater monitoring program be pro-active in detecting pollution before the groundwaters are polluted, such as through the use of unsaturated flow monitoring of the groundwater underlying the areas receiving the waste residues.
\end{abstract}

This paper provides guidance on the use of the OECD eutrophication study results to evaluate the potential impacts of nutrient releases from agricultural lands and other sources on the eutrophication related water quality in many types of waterbodies. It also provides guidance on how to establish allowable nutrient loads to waterbodies to protect the eutrophication related designated beneficial uses. Particular attention is given to assessing the water quality significance of nitrogen and phosphorus present in stormwater runoff/irrigation return waters from the areas that receive land application of inorganic fertilizers and waste residues. It discusses monitoring programs needed to ensure that land application of inorganic fertilizers and waste

${ }^{1}$ Accepted for presentation at the AWWA/WEF/CWEA Joint Residuals and Biosolids Management Conference San Diego, CA February(2001) 
residues do not cause or contribute to impairment of the beneficial uses of surface or ground waters for domestic water supply, for the propagation of aquatic life, and/or for recreational purposes.

\section{KEYWORDS}

inorganic fertilizer, nitrate, phosphate, land application, biosolids, animal manure, compost, water quality impacts, eutrophication.

\section{INTRODUCTION}

As part of implementing the Clean Water Act requirements for Total Maximum Daily Loads (TMDLs), the US EPA (1999) and many states are developing control programs for aquatic plant nutrients (nitrogen and phosphorus compounds) in wastewater discharges, irrigation return/drainage water and stormwater runoff. Many waterbodies in the US are already listed as 303(d) "impaired" because of excessive aquatic plant growth in surface waters; the number of listings of this type will likely increase significantly when the US EPA $(1998,2000 a)$ and the states develop chemical-specific water quality criteria for nitrogen and phosphorus compounds intended to control excessive fertilization of waterbodies. Also of concern is the potential for nitrogen compounds invarious types of fertilizers and wastes derived from municipal, industrial and agricultural activities to cause groundwater pollution. In many situations shallow groundwaters that are polluted by nitrate, discharge to nearby watercourses and thereby increase the nutrient load to those waterbodies.

Agricultural activities that lead to greater nitrogen and phosphorus discharges to surface waters compared to nutrient fluxes from undeveloped, native land are under increased scrutiny. Of particular concern is the use of inorganic and organic fertilizers for enhanced crop production. This situation will elicit evaluation of land-based waste management, such as of biosolids (sewage sludge), compost, and manure. While it is argued that the nitrogen in biosolids or compost should not be treated any differently from the inorganic nitrogen used for crop production, in reality, because of the opposition to the use of biosolids in crop production, lands that receive biosolids could readily be subjected to greater restriction because of their being a source of nitrogen and phosphorus that leads to excessive fertilization in waterbodies receiving the runoff/discharges.

This paper reviews issues that should be evaluated in connection with the use of inorganic fertilizers and the land application of biosolids and other waste solids that are high in nutrients. While the focus of the paper is on agricultural areas as sources of nutrients, it is equally applicable to municipal and industrial wastewater discharges and urban stormwater runoff. Much of what is presented herein is applicable to evaluating the appropriate use and regulation of fertilizers on urban residential and commercial properties.

This paper also provides an overview discussion of the authors' and their associates' work devoted to developing and applying the Vollenweider-OECD eutrophication modeling approach for managing excessive fertilization of waterbodies. As discussed and demonstrated, this approach is an extremely powerful and reliable tool that can be readily used to help determine the degree of nutrient control needed to achieve desired water quality in a waterbody impacted by nutrients. 


\section{EFFECTS OF NUTRIENTS ON WATER QUALITY}

The aquatic plant nutrients, nitrogen and phosphorus stimulate the growth of a variety of types of aquatic plants. When present in excessive amounts, these plants can significantly impair the use of waterbodies for a number of purposes. In addition to planktonic and attached algae, excessive fertilization can, under certain conditions, lead to the development of excessive amounts of higher aquatic plants, such as water weeds (e.g., water hyacinth) and other plants that are adverse to the beneficial uses of a waterbody.

Lee (1971) summarized how aquatic plants can adversely impact the beneficial uses of waterbodies. Use of the water for domestic water supply can be adversely affected in several ways. Planktonic (suspended) algae and, in some cases, attached algae can cause tastes and odors in a domestic water supply. Planktonic algae can also cause shortened filter runs, increased chlorine demand, and interference with disinfection. Further, as discussed by Lee and Jones (1991a) under unusual circumstances, algae can increase the total organic carbon (TOC) in the waterbody and thereby lead to increased trihalomethanes upon disinfection with chlorine.

One of the most significant impacts of excessive fertilization of waterbodies is an impairment of the recreational uses. Excessive growths of algae and other aquatic plants can have a significant adverse impact on the aesthetic quality of the water, and contact and non-contact recreation including boating, swimming, wading, and participating in shoreline activities. These issues were reviewed by Vollenweider (1968) and Lee (1971).

Excessive fertilization of a waterbody, suchas Chesapeake Bay, has apparently led to the growth of certain algae (Pfiesteria) that are toxic to fish. Further, in some situations, either naturally derived nutrients or those derived from cultural sources lead to "red tides," in whichexcessive growths of certain types of algae, some of which may be toxic, occur. An area of the Gulf of Mexico is experiencing hypoxia (low dissolved oxygen) which is apparently related to the algal growth in the surface waters of the Gulf. According to the US EPA (2000b), the hypoxia is strongly correlated with nutrient discharges from the mouth of the Mississippi River. This river drains 40 percent of the lower 48 states; its watershed is home to almost a third of the US population. The Gulf of Mexico hypoxia situation has stimulated the US EPA and states to explore developing nutrient control programs in the Mississippi River watershed. Increased attention will be given to the sources of nutrients in the Chesapeake Bay and the Mississippi River watersheds that are causing excessive fertilization of the Bay and the Gulf of Mexico.

Excessive fertilization of a waterbody can stimulate sufficient aquatic plant growth so that it impairs the fisheries of a waterbody. While the addition of nutrients stimulates overall fish production, as discussed by Lee and Jones (1991b), excessive fertilization can also significantly adversely impact the quality of fish, changing the populations from desirable gamefish to rough fish such as carp. The decomposition of excessive planktonic algae can cause deoxygenation of the hypolimnion of a waterbody and, if severe, lead to significant dissolved oxygen depletion in the surface waters as well. While somewhat unusual, an example of this type of situation occurs in the San Joaquin River Deep Water Ship Channel near Stockton, CA. There, nutrients derived primarily from agricultural sources in the San Joaquin River watershed 
stimulate sufficient algae to lead to depletion of the oxygen resources to levels below water quality standards throughout the water column, including surface waters (Lee and Jones-Lee, 2000a,b). This situation arises from the biochemical oxygen demand (BOD) of the algae which exerts an oxygen demand in the water column and contributes to biotic and abiotic oxygen demand in the sediments.

The diel(24-hr) cycle of oxygen production (photosynthesis) and consumption(respiration) associated with algal growth causes increases and decreases in dissolved oxygen concentration over the course of a 24-hr period. How low the dissolved oxygen concentration goes and the duration of the decreases affect how this phenomenon can impact fish. The issue that should be addressed is what it means to the aquatic life resources of the waterbody to have excursions of dissolved oxygen below the $5 \mathrm{mg} / \mathrm{L}$ criterion for a few hours each day. These excursions can be as much as 1 to $2 \mathrm{mg} / \mathrm{L}$ or so below the standard during periods when there are significant algal populations in the near-surface waters.

DO depletions below $5 \mathrm{mg} / \mathrm{L}$ affect the rate of growth of fish and other aquatic life. The altered fish growth rates are small for minor depletions below $5 \mathrm{mg} / \mathrm{L}$; however, depletions down to $3 \mathrm{mg} / \mathrm{L}$ are acutely lethal to some fish (US EPA, 1986, 1987). An important part of developing a nutrient control program is to clearly define the DO water quality objective violations that are to be controlled by nutrient management. In some instances, because of the high cost associated with meeting worst-case-based water quality standards for dissolved oxygen, it may be necessary to develop a special classification of aquatic life-related beneficial uses of waterbodies, which would allow some minor impairment of the beneficialuses due to DO depletions below the water quality objective associated with diel or near-sediment/water interface excursions below the objective.

\section{FACTORS INFLUENCING THE RELATIONSHIP BETWEENALGAL NUTRIENTS ADDED TO A WATERBODY AND WATER QUALITY PROBLEMS}

Aquatic plant nutrients $\mathrm{N}$ and $\mathrm{P}$ exist in a number of forms; some are available, and others are unavailable to support algal growth. Nitrate and ammonia are typically available forms of nitrogen. While organic nitrogen, when converted to ammonia, is available, part of the organic nitrogen is not readily convertible to ammonia through ammonification reactions. For phosphorus, it is the soluble orthophosphate that is available to support algal growth. Many forms of particulate phosphorus, e.g., the phosphorus associated with inorganic particulates, are not available and typically are not readily converted to available forms. Some forms of particulate phosphorus, such as algal cells, are converted through mineralization reactions, to soluble orthophosphate, which supports algal growth. Based on the review by Lee et al. (1980), for many situations the amount of available phosphorus in a waterbody can be estimated to be equal to the soluble orthophosphate plus about 20 percent of the particulate phosphorus.

The stoichiometry of algae is typically 106 carbon to 16 nitrogen to one phosphorus on an atomic basis, or 7.5 nitrogen to one phosphorus on a mass basis. Based on the stoichiometric composition of algae, typically either nitrogen or phosphorus is the element present in the algal environment which when supplied at a rate less than needed, can limit the growth of algae - i.e., is the limiting element. This is important in managing eutrophication-related water quality impairment since increasing the supply of available limiting 
nutrient increases algal biomass. Similarly, reducing the amount of the limiting nutrient available can effect reduction in algal biomass.

There is considerable confusion about how to determine the limiting nutrient in waterbodies. Often, attempts are made to apply the so-called "Redfield numbers" (algal stoichiometry relationships) to predict limiting nutrients where if the ratio of the concentrations of available $\mathrm{N}$ to $\mathrm{P}$ are greater than 7.5 to one, phosphorus is said to be limiting. In fact, this approach is not valid, unless the actual concentration of $\mathrm{P}$ at peak biomass is at or below a growth-rate-limiting concentration. Growth-rate-limiting levels are on the order of about $5 \mu \mathrm{gP} / \mathrm{L}$ for soluble orthophosphate and about $20 \mu \mathrm{gN} / \mathrm{L}$ for nitrate plus ammonia as $\mathrm{N}$. If the concentrations of soluble orthophosphate and available nitrogen are greater than these amounts, the rate of growth of the algae is not limited by nutrients, but rather by other factors, usually light. The approach for reliably determining limiting nutrients in a waterbody, as described by Lee and Jones-Lee (1998a), involves determining the concentrations of available $\mathrm{N}$ and $\mathrm{P}$ at maximum algal biomass. If the concentrations of available $\mathrm{N}$ or $\mathrm{P}$ are greater than growth-rate-limiting concentrations under these conditions, then that nutrient is not limiting.

Algae can grow to a sufficient extent to shade themselves and, thereby, limit their further growth. Inorganic turbidity, such as is associated with erosion, and color in the waterbody can also reduce light penetration sufficiently to cause the algal biomass in the waterbody to be less than it would be if the turbidity and color were not present. While inorganic turbidity and color can slow the rate of algal growth, in order for those conditions to limit the ultimate biomass that develops, the concentrations of inorganic turbidity would have to be quite high; this can occur when Secchi depth is less than about $0.2 \mathrm{~m}$ (Lee et al., 1980; Ortiz et al., 1981).

\section{CRITICAL NUTRIENT CONCENTRATIONS}

The US EPA(1998, 2000a) is attempting to develop chemical-concentration-based, numeric water quality criteria/standards for nutrients. The US EPA's proposed approach is to define a critical nutrient concentration for a particular ecoregion and type of waterbody, e.g., river, lake, or estuary. This critical nutrient concentration, which would become the state water quality standard, would be applied to all waterbodies of the particular type. It is the experience of the authors, however, that this approach can lead to inappropriate evaluation and regulation of critical nutrient concentrations for many waterbodies. As discussed herein, the approach that should be used to determine the appropriate nutrient load/concentration should be based on a site-specific evaluation considering the waterbody's nutrient load, and morphological and hydrological characteristics. Further, as discussed below, the critical concentration of a nutrient is related to the response of the public in the particular area to the growth of algae or other aquatic plants. Rather than eutrophication response being controlled by a US EPA-defined "ecoregion," it is more appropriately adjusted to a geographical area reflecting the range of eutrophication-related water quality characteristics of the waterbodies of the area. The public's response to excessive fertilization as it impacts recreational use, depends to a considerable extent on their experience/exposure to excessively fertile waterbodies. 
As originally proposed, the US EPA's proposed numeric nutrient criteria/standards would be applied in ways similar to the standards for heavy metals and various organics where an exceedance of the standard value would cause the waterbody to be considered "impaired," which would, in turn, lead to the development of nutrient control programs through a TMDL. Typically, successful nutrient control programs focus on controlling the limiting nutrient input to the waterbody. It may be possible in some situations to control the particular nutrient input to the waterbody to make it limiting. For most freshwaters, available phosphorus is the element that is either limiting or can be made limiting for algal growth. In some areas, especially on the West coast of the US and in many marine waters, nitrogen is the element that is more likely to limit algal growth. In heavily impacted areas, such as those receiving large amounts of domestic and some types of industrial wastewaters and/or agricultural runoff, neither element is limiting. Under these conditions, it is normally more cost-effective to controlphosphorus inputs fromwastewaters and agricultural runoff than nitrogen (Lee and Jones, 1988).

\section{MANAGING EXCESSIVE FERTILIZATION}

Waterbodies exist in various degrees of natural fertility, from highly oligotrophic, with very few algae, through hypereutrophic, with massive naturally occurring algal blooms. The cultural activities of man (farming, development of municipalities, and industry) in a waterbody's watershed can greatly increase the flux of nitrogen and phosphorus to a waterbody. The issue of primary concern in managing excessive fertilization of a waterbody is the impact of cultural activities in a watershed on the increased fertility above the natural fertility that would be present in the waterbody. In the 1950s and 1960s, it was recognized that the excessive fertilization of waterbodies was one of the major causes of water quality/use-impairment.

The US EPA (2000b) has recently released its latest National Water Quality Inventory. This inventory presents the US EPA's Clean Water Act Section 305(b) 1998 report to Congress on the condition of US waterbodies. It shows that the states that are the source of information for the inventory, have concluded that about 45 percent of the lakes, reservoirs, and ponds had impaired water quality due to nutrients. Further, 30 percent of the lakes included in the inventory were impaired due to constituents (nutrients, sediments, atmospheric deposition, etc.) derived from agricultural sources. About 12 percent of the impaired lakes were impaired because of constituents in wastewater sources discharged to them. As indicated in the US EPA (2000b) National Water Quality Inventory, excessive fertilization of waterbodies is one of the most significant causes of water quality impairment in the US.

Substantial literature was developed in the 1960s and 1970s devoted to managing excessive fertilization of waterbodies. It was established, primarily by Vollenweider $(1975,1976)$, that the impact of nutrients on a waterbody (lake or reservoir) is dependent not only on its nutrient loads/concentrations but also on the morphology (mean depth) and hydrology (hydraulic residence time) of the waterbody. This situation makes the US EPA's attempts to develop standardized, ecoregion-wide critical loads/concentrations of nutrients to waterbodies questionable. While there is a variety of modeling approaches (Ambrose et al., 1988, 1993a,b; Bowie, 1985; US EPA, 1997) that can be used to attempt to relate nutrient loads to a waterbody to the waterbody's planktonic algal growth, the most comprehensive and reliable approach is the result of the Vollenweider-OECD eutrophication study. This study was a 22-country, 200-waterbody, 
\$50-million effort that took place over a five-year period in the 1970s in Western Europe, North America, Japan and Australia (OECD, 1982; Vollenweiderand Kerekes, 1980). Figure 1 presents the relationships developed from the Vollenweider-OECD studies for the US waterbodies (Rast and Lee, 1978; Lee et al., 1978).

Figure 2 presents the database that exists now, which is in excess of 750 waterbodies located in various parts of the world (Jones and Lee 1982a, 1986). The abscissa in Figures 1 and 2 is Vollenweider's normalized phosphorus load. This normalized load to a lake or reservoir is approximately equal to the average annual concentration of phosphorus in the waterbody. As shown in these figures, there is remarkably good agreement between the normalized phosphorus load (in-lake phosphorus concentration) and the average planktonic algal chlorophyll. Each of the dots shown in Figure 2 represents a waterbody that has been evaluated by a nutrient load eutrophication response study conducted over at least one year. A wide range of types of waterbodies is represented, including a permanently ice-covered Antarctic lake (Jones-Lee and Lee, 1993), shallow farm ponds, and Lake Superior in the US-Canadian Great Lakes. They include several estuarine and near-shore marine waters as well (Lee and Jones, 1981, 1989).

Lee and Jones (1991b) compiled information on the relationship between phosphorus loads to waterbodies and their yields of fish (Figure 3). This figure shows that there is a good relationship between the normalized phosphorus load and the fish biomass present in a waterbody. As Lee and Jones (1991b) discussed, as the nutrient loads increase there is a shift in the type of fish that are present. In temperate climates, nutrient-poor waterbodies that stratify and thereby maintain cooler waters in the summer in the hypolimnion, can maintain coldwater fisheries. However, as the fertility of the waterbody increases, deoxygenation of the hypolimnion leads to sufficient DO depletion to prevent coldwater fish from oversummering in that area.

As discussed by Jones and Lee (1988), the relationships shown in Figures 1, 2, and 3 can be used to evaluate overall ecosystem functioning with respect to relating nutrient loads to primary and secondary production. Of particular concern is whether there are toxicants in the waterbody that are inhibiting aquatic organism production at various trophic levels. It is the experience of the authors that with few exceptions, the relationships shown in Figure 2 are applicable to a wide variety of waterbodies located throughout the world.

Based on the normalized phosphorus load to waterbodies, it is possible to predict, with sufficient reliability for management purposes, the planktonic algal chlorophyll that should be present in the waterbody and, most importantly, how changing the phosphorus load to the waterbody will change the overall planktonic algal chlorophyll content of the water. As discussed by Rast et al. (1983), the relationships shown in Figures 1 and 2 can be used to evaluate the impact of adding or removing an amount of phosphorus from a particular source on the overall fertility of the waterbody. 
Figure 1 - P Loading/Eutrophication-Related Water Quality Response Relationships for US Waterbodies (After Jones and Lee, 1982a)
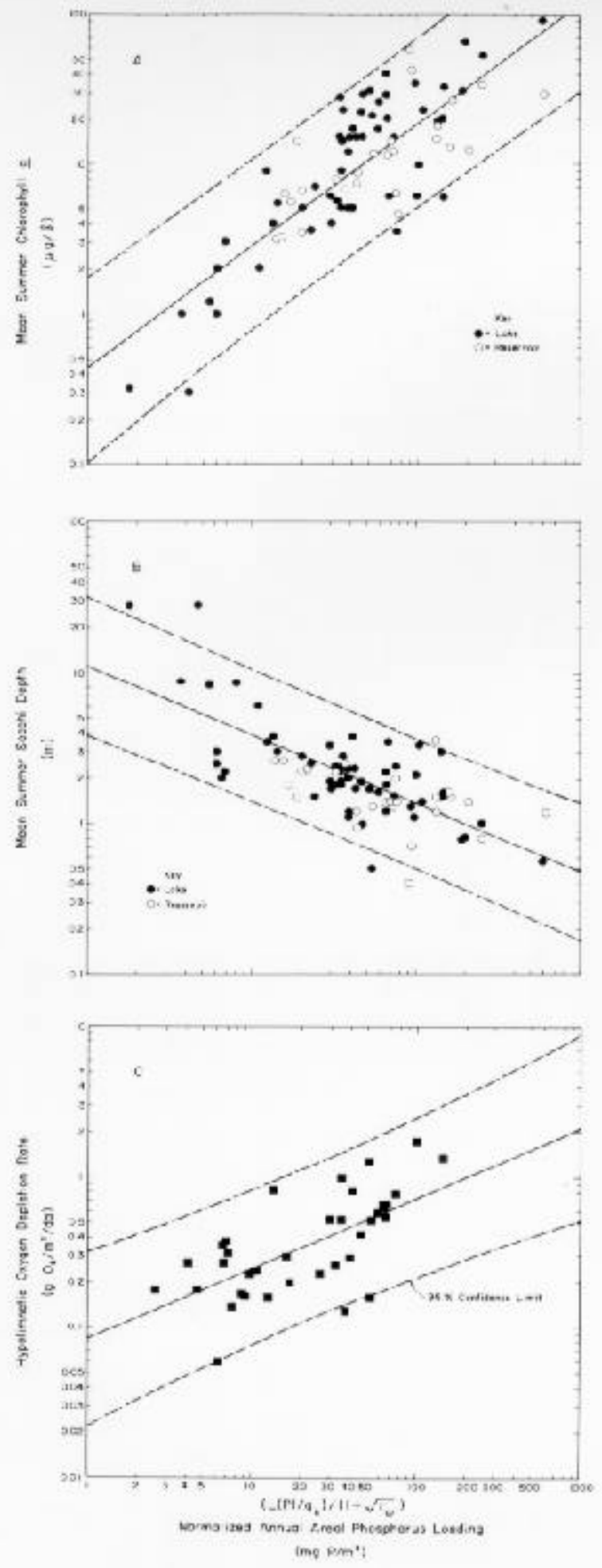

KEY

$L(P)$ * Areal Annuol Phosoharus Load ( $\mathrm{mg} \mathrm{P} / \mathrm{m}^{2} / \mathrm{yr}$ )

$q_{g}=$ Mean Depth - Hydraulic Res dence Time $=\bar{z} / \tau_{\omega}$ $(\mathrm{m} / \mathrm{yr})$

$\tau_{\omega}=$ Hydrgulic Residence. Time (yr) 
Figure 2 - Updated Vollenweider-OECD Normalized P Loading/Chlorophyll Response Relationship (After Jones and Lee, 1986)

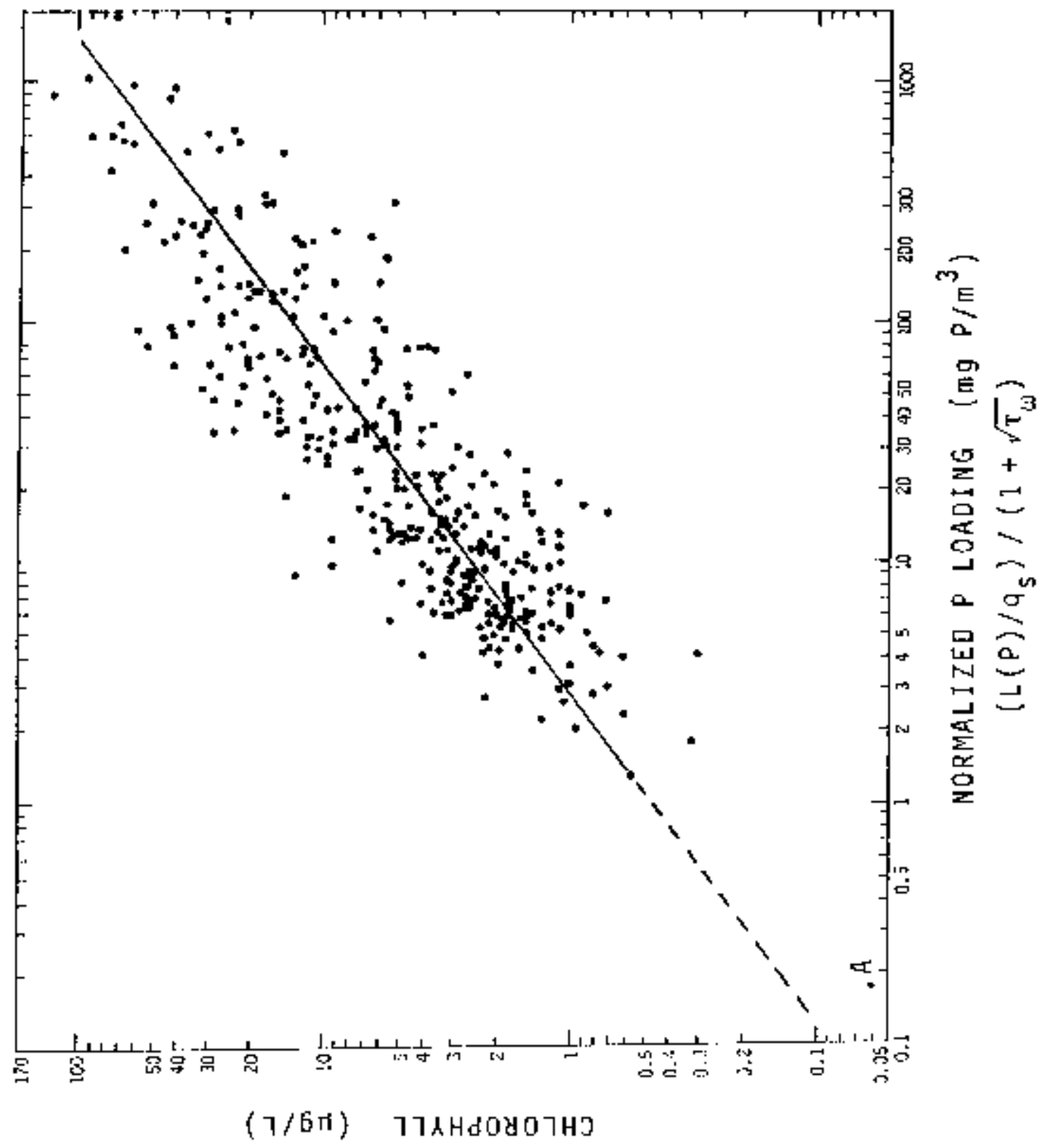


Figure 3 - Relationship between Normalized P Load and Fish Yield (From Lee and Jones, 1991b)

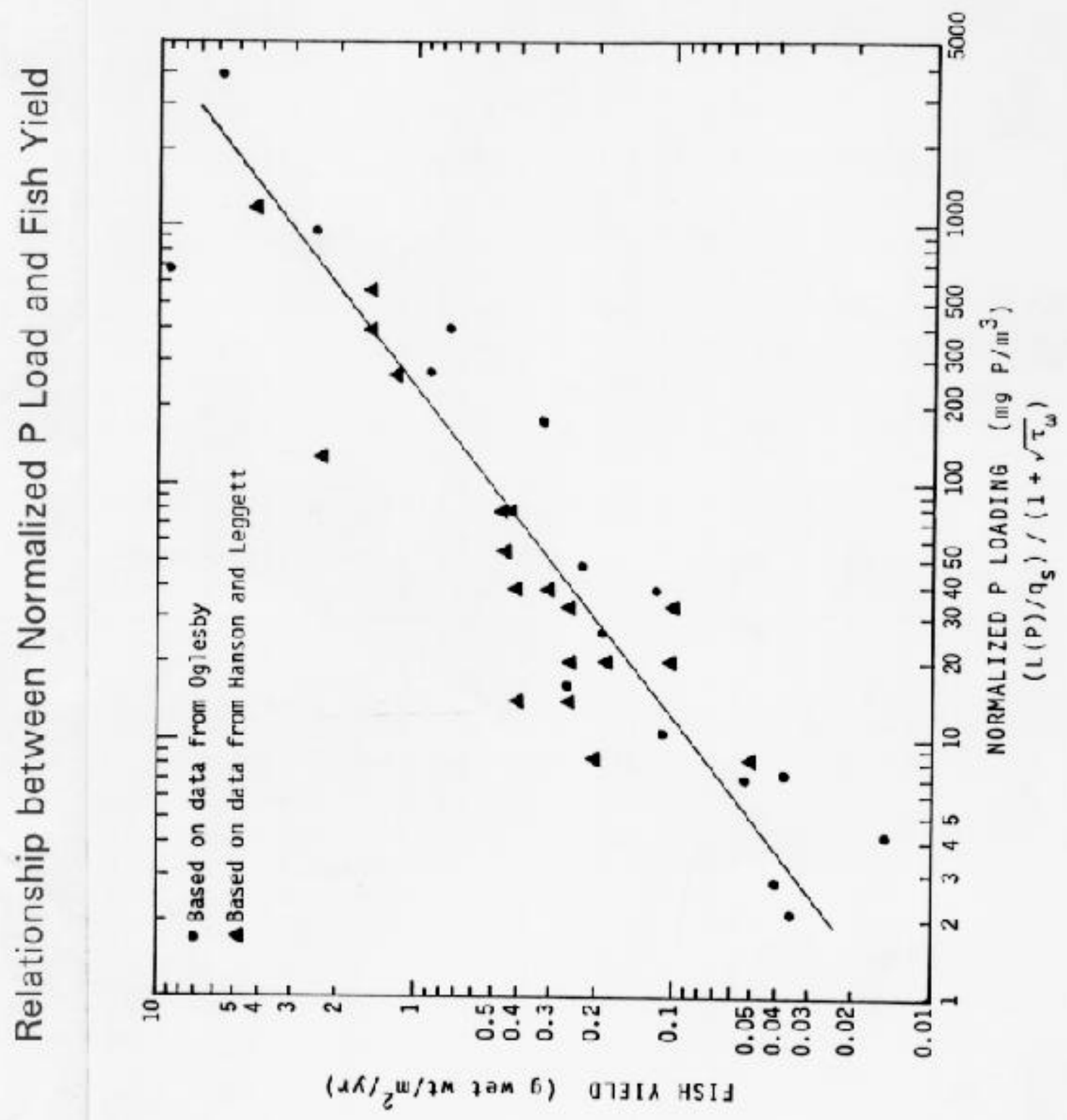

An example of an application of the Vollenweider-OECD eutrophication study results to managing water quality in a domestic water supply reservoir has been provided by Archibald and Lee (1981). They have shown how the planktonic algal chlorophyll in Lake Ray Hubbard, a water supply reservoir for the city of Dallas, TX, will change as a result of altering the phosphorus loads to the lake fromits watershed. Changes 
in the planktonic algal chlorophyll in a water supply reservoir can be correlated with characteristics of concern to water supplies including algal tastes and odors, and length of filter runs (Jones and Lee, 1982b).

\section{REGULATION OF BIOSOLIDS NITROGEN APPLICATION RATES}

Previously, the application of biosolids to land was regulated primarily by heavy metal concentrations in the biosolids, in order to meet the US EPA Rule 503 requirements. Today, with the increased emphasis on controlling excessive fertilization of waterbodies, consideration is being given to meeting nitrogen and, in some areas, phosphorus loadings to the soil to prevent surface and/or ground water pollution. In the past and in some areas today, little or no regard is given to whether the nitrogen in biosolids (or for that matter, in animal manure or compost) typically in the form of organic nitrogen and ammonia, converts to nitrate, which leads to surface or ground water pollution.

The primary objective of current biosolids application rates, with particular emphasis on nitrogen, is to achieve "agronomic rates" of application. Basically, this is interpreted as the application of biosolids nitrogen (organic nitrogen, ammonia, nitrite and nitrate) to match the normal inorganic fertilizer application rates that are used in crop production. Since typical agronomic rates of inorganic and organic fertilizer application can lead to surface water runoff that fertilizes receiving waters and to groundwater pollution by nitrate, the development of TMDLs to control excessive fertilization of waterbodies could, in many areas, lead to a significant reduction in the rates of allowed fertilizer application for inorganic as well as organic sources. Particular attention will likely be given to waste management practices, such as application of biosolids, animalmanure, and compost, because of some individual aversion to using waste-derived sources of nutrients in agricultural crop production.

Gilmour et al. (2000) recently completed a Water Environment Research Foundation (WERF) project devoted to developing approaches for estimating agronomic rates of nitrogen application associated with biosolids. That project involved assessing the amounts of organic nitrogen present in biosolids from a variety of sources around the country that become available to support plant growth under field conditions in several areas of the U.S. The project yielded results that can be used to estimate the biosolids application rates that match agronomic rates, considering the factors that control the conversion of organic nitrogen to ammonia and nitrate. However, no consideration was given in the project to whether meeting agronomic rates would lead to surface or ground water pollution. It was acknowledged that whatever pollution occurs associated with meeting agronomic rates for a particular fertilizer rate of application could also occur from the biosolids application.

One of the important observations from this study was that on the order of 30 percent of the organic nitrogen that is present in biosolids is not mineralized during the growing season of application, but is carried over to the next winter. This leads to a difference in the behavior of biosolids and, presumably, manure and compost, from inorganic fertilizers. While the rate of application of inorganic fertilizer can potentially be more closely matched to the crop needs during a particular season, the organic sources of nitrogen (biosolids, manure, and compost) have the potential to be carried off the property in stormwater runoff during the winter. Also, there is a slow rate of mineralization during the winter/spring period which would 
occur during non-growing seasons, and, therefore, could lead to transport from the area of application to surface or groundwaters.

\section{MONITORING NITROGEN LOSSES FROM LAND RUNOFF AND GROUNDWATER RECHARGE}

As part of the US OECD eutrophication studies, Rast and Lee (1983) examined data available as of the mid-1970s fromabout 100 watersheds located across the US for the amounts of nitrogen and phosphorus released/exported to surface waters from these watersheds. A summary of the results obtained in that study is presented in Table 1. As shown in Table 1, for most of the US rural/agricultural areas contributed about $0.5 \mathrm{~g} / \mathrm{m}^{2} / \mathrm{yr}$ of nitrogen and $0.05 \mathrm{~g} / \mathrm{m}^{2} / \mathrm{yr}$ phosphorus. In the western US, the nitrogen export from rural/agricultural lands was found to be $0.2 \mathrm{~g} / \mathrm{m}^{2} / \mathrm{yr}$. This difference is apparently related to the atmospheric contribution of nitrogen to land found in the western states compared to that of the eastern states. This difference is an important reason that algalgrowth in lakes in the Midwest and East is typically phosphoruslimited.

Table 1 - Amounts of Nitrogen and Phosphorus Contributed from Various Sources

\begin{tabular}{|l|l|l|l|}
\hline Source & Nitrogen & Phosphorus & Units \\
\hline Domestic Wastewater & 3.2 & 0.9 & $\mathrm{~kg} / \mathrm{person} / \mathrm{yr}$ \\
\hline Urban Drainage & $0.5\left(0.25^{\mathrm{a}}\right)$ & 0.1 & $\mathrm{~g} / \mathrm{m}^{2} / \mathrm{yr}$ \\
\hline Rural/Agriculture & $0.5\left(0.2^{\mathrm{a}}\right)$ & 0.05 & $\mathrm{~g} / \mathrm{m}^{2} / \mathrm{yr}$ \\
\hline Forest & $0.3\left(0.1^{\mathrm{a}}\right)$ & $0.01-0.001$ & $\mathrm{~g} / \mathrm{m}^{2} / \mathrm{yr}$ \\
\hline $\begin{array}{l}\text { Manured Land } \\
\left(100 \text { cows } / \mathrm{mi}^{2}, 15 \text { tons manure/cow/yr }\right)\end{array}$ & 0.34 & 0.11 & $\mathrm{~g} / \mathrm{m}^{2} / \mathrm{yr}$ \\
\hline Drained Marsh & 10.1 & 4.5 & $\mathrm{~g} / \mathrm{m}^{2}$ \\
\hline Rainfall and Dry Fallout & 2.4 & 0.02 & $\mathrm{~g} / \mathrm{m}^{2} / \mathrm{yr}^{\mathrm{b}}$ \\
\hline
\end{tabular}

$\mathrm{a}=$ For Western US Waterbodies; $\mathrm{b}=$ Waterbody Area; (after Rast and Lee, 1983)

As shown in Table 1, the export of $\mathrm{P}$ from rural/agricultural lands that have manure from 100 cows per square mile is about twice that from rural/agricultural lands without cattle.

There is need to update/verify the Rast and Lee (1983) findings to examine in detail how various types of agricultural activities in various parts of the US impact nitrogen and phosphorus export to surface waters from land. Further, and most importantly, nutrient export studies should be conducted in areas that receive biosolids, manure, and compost as well as inorganic fertilizers, to determine whether application of the organic forms of nitrogen in biosolids, etc., at agronomic/comparable rates, leads to different nitrogen export from various types of agricultural activities. A particular concern is the issue of the partial mineralization of the organic nitrogen that was found by Gilmour et al. (2000) during the growing season leading to increased nitrogen export during the non-growing season. 


\section{Groundwater Pollution}

There is an urgent need for agricultural interests and regulatory agencies to change the approach being used to regulate the pollution of groundwaters by inorganic and organic fertilizers/waste. The current approach involves finding excessive concentrations of nitrate in groundwaters that are a threat to the use of groundwaters for domestic water supply purposes, and then concluding that there is need to restrict agricultural activities to stop further pollution. Rarely, however, have regulatory agencies taken action to actually prevent groundwater pollution by nitrate.

The current, passive approach, in which agricultural activities/waste management are allowed to occur with limited restrictions, should be replaced by a pro-active approach designed to detect incipient groundwater pollution by nitrate before widespread pollution occurs. There could come a day when the application of inorganic or organic fertilizers to land is controlled to prevent or greatly minimize groundwater pollution by nitrate. In order for such an approach to be implemented it will be necessary to develop programs to reliably monitor the concentration of nitrate in unsaturated/saturated flow within the vadose zone under agricultural fields and waste management areas. It is possible, through the use of vacuum cup lysimeters, to collect the flow through the vadose zone associated with precipitation and/or irrigation events and measure the concentrations of nitrate in this unsaturated/saturated flow. An example of this approach was provided by George et al. (1986).

It is important to understand that much of the nitrate, and many other groundwater pollutants, are transported through the vadose zone in saturated/wetted front flow associated with precipitation/irrigation events. The actual amount of transport under average vadose zone moisture conditions is probably insignificant for nitrate transport. Therefore, the vacuum cup lysimeters would need to be operated so that they can capture the short-term pulses of nitrate that occur in wetted fronts associated with precipitation/irrigation events.

Appropriate vadose zone monitoring of nitrate transport coupled with highly selective monitoring of the upper few feet just under the water table will allow an assessment of the comparative impacts of the various types and rates of fertilizer applications, soils, and crop conditions that lead to groundwater pollution by nitrate. It is important that this type of monitoring begin to be implemented on a large-scale basis throughout the US in order to determine the allowable inorganic as well as organic (biosolids, manure, and compost) loadings that can be permitted without causing groundwater pollution by nitrate.

Ordinarily, phosphorus is not transported to a significant extent in groundwaters because phosphate tends to sorb onto aquifer particles. However, as discussed by Jones and Lee (1979), there are situations in which phosphate is transported in groundwater systems. These occur in non-calcareous quartz sand aquifers which also have low iron content. Quartz sand typically has low sorption capacity for phosphate. Calcium carbonate particles (calcite or aragonite) can precipitate phosphate on the surface of the particles as hydroxyapatite. Also, iron coatings on quartz particles can sorb phosphate, thereby reducing its mobility in an aquifer. 


\section{RECOMMENDED APPROACH FOR EVALUATION OF ALLOWED INORGANIC AND ORGANIC FERTILIZER APPLICATIONS BASED ON NITROGEN EXPORT}

There are some who espouse, as part of eutrophication management programs, that "every little bit" of nutrient control helps. This claim, however, is not supported by knowledge of how nutrients impact eutrophication-related water quality of waterbodies. Lee and Jones (1986) found that at least a 20 to 25 percent reduction in a nutrient load to a waterbody is needed to produce a discernible improvement in the eutrophication-related water quality of the waterbody. Except for those situations where a major point source, such as a domestic wastewater discharge, is the primary source of nutrients for a waterbody, eutrophication management programs should be based on watershed-based approaches in which all sources of available forms of nutrients are evaluated with respect to their impact on the excessive fertilization water quality problem of a particular waterbody. The components of a watershed-based eutrophication management program are summarized below. This summary is based on a review by Lee (1999) concerned with managing nutrients in the San Joaquin River Deep Water Ship Channel watershed that lead to excessive growth of algae that, in turn, causes DO depletionin the Ship Channel to levels below the water quality standards.

\section{Define the Eutrophication-Related Water Quality Problem}

It is extremely important to properly define the water quality problem(s) caused by excessive nutrient input to a waterbody of concern. As part of defining the problem, a consensus should be developed by the stakeholders concerned about the problem and its management, on the degree of control of the use impairment that is desired. For domestic water supplies, this would likely focus on the frequency of noxious algal blooms that cause tastes and odors or shortened filter runs. For recreational use of waters, water clarity controlled by planktonic algae (Secchi depth), is a measure that can be used to relate planktonic algal growth to water quality/use-impairment.

Lee et al. (1995a,b,c) discussed an approach for establishing the desired trophic state (degree of fertility) for a waterbody. Particular attention was given to water clarity (Secchi depth) as a quantitative indicator of the aesthetic quality of the water. As shown in Figure 1 and discussed in detail by Lee et al. (1995c), there is an inverse relationship between the Secchidepthand the planktonic algal chlorophyll in waterbodies in which Secchi depth is controlled by planktonic algae. If inorganic turbidity or color significantly impact light penetration, then the Secchi depth will be less than that predicted based on the planktonic algal chlorophyll content of the water.

Low dissolved oxygen concentrations in the hypolimnion (hypoxia) is an important consequence of excessive fertilization of waterbodies that density stratify due to temperature and/or salts. Figure 1c (lowest) shows the initial results developed by Rast and Lee (1978) relating the normalized phosphorus load to a waterbody to the rate of hypolimnetic oxygen depletion. As discussed by Lee and Jones-Lee (1995), depletion of dissolved oxygen in the hypolimnion of a waterbody is controlled by the BOD of the algae raining down through the thermocline and the oxygen demand of the sediments, as well as the volume of the hypolimnion. Fitzgerald (1964) made measurements of the oxygen demand of algae, which, on a mass basis, is similar to that of domestic wastewaters. The oxygen demand of sediments is normally 
primarily due to abiotic reactions involving ferrous iron and sulfides. It is possible, through relatively simple models, to relate these two sources of oxygen demand to the amount of planktonic algal chlorophyll that develops in the surface waters of a waterbody. As a result, it is possible to relate the nutrient loads to a waterbody to its hypolimnetic oxygen depletion rate. The impact of the hypolimnetic oxygen depletion rate on the water quality - i.e., on dissolved oxygen concentration, depends on the volume of the hypolimnion which is a function of the waterbody's morphology.

Lee (1970) reviewed the factors influencing the exchange of oxygen demand and other constituents associated with waterbody sediments. He pointed out that the primary mechanism for this exchange is the degree of mixing of the sediments into the overlying water column, which enables the constituents, including oxygen demand associated with the interstitial waters of the sediments, to be mixed into the water column waters near the sediment/water interface. This mixing process is controlled primarily by physical processes, suchas currents induced by water movement near the sediment/water interface. Also, biological processes, such as anaerobic production of methane and $\mathrm{CO}_{2}$ can be a mechanism for stirring of sediments. Aquatic organism foraging and bioturbation are also important mechanisms for mixing of sediments, and thereby promoting sediment/water exchange reactions.

It is important to understand that the Vollenweider-OECD as well as other eutrophication modeling efforts are applicable only to planktonic algae. They do not reliably predict how nutrients impact attached algae or attached or floating water weeds/macrophytes such as water hyacinth. Lee et al. (1995b) suggested that water quality problems associated with these types of aquatic plants can best be related to percent of the waterbody surface area covered by them.

The US EPA's current approach for developing chemical-concentration-based nutrient criteria and standards focuses on defining nutrient concentrations in an "ecoregion" of the country that represents the concentration of nutrients (total $\mathrm{N}$ and total $\mathrm{P}$ ) that would occur without cultural activities of man in the waterbody's watershed. The Agency hopes to be able to relate the nutrient concentrations to a water quality parameter such as chlorophyll or Secchi depth. Lee and Jones-Lee (1998b) have discussed problems with the US EPA's proposed approach for developing chemical-specific nutrient criteria. Thus far in its nutrient criteria development, the Agency is largely ignoring the vast amount of work that was done in the 1960s and 1970s relating nutrient loads and concentrations to eutrophication-related water quality. By focusing on nutrient concentrations rather than nutrient impacts, the Agency's approach can provide unreliable information on the degree of nutrient control needed for a particular waterbody to achieve the desired water quality.

The approach advocated by the authors of this paper, of focusing on a eutrophication-related water quality problem and then defining the nutrient and other factors that control this problem, is a far more reliable, technically valid approach than that being advanced by the US EPA. Eutrophication management programs must be focused on controlling real, significant water quality problems in each waterbody of concern, and evaluate the factors that influence how a particular nutrient load impacts the water quality problem of the waterbody, and how its manipulation will change water quality. 


\section{Assessing Limiting Nutrient(s) and their Sources}

As part of its efforts to develop water quality criteria for nutrients, the US EPA (2000a) is attempting to use total phosphorus, rather than algal-available phosphorus, as the basis for nutrient criteria/standards. This approach can readily lead to significant errors in relating phosphorus loads to waterbodies to the planktonic algal chlorophyll that can develop from the P load. While the relationships shown in Figures 1 and 2 are based on a normalized total phosphorus load, the data shown in these figures are for waterbodies in which most of the added phosphorus was in an algal-available form, i.e., soluble ortho-P, or particulate phosphorus that can readily be converted to soluble ortho-P. As discussed above, only about 20 percent of the particulate phosphorus in land runoff from agricultural or urban areas, can be expected to be converted to algal-available phosphorus (Lee et al., 1980). There are waterbodies in which most of the phosphorus added to the waterbody is associated with inorganic particles because of high rates of erosion in the watershed. Under these conditions, the algal-available phosphorus load should be initially estimated based on the general finding that soluble ortho-P plus 20 percent of the particulate phosphate load is available to support algal growth. Site-specific investigations incorporating algal assay procedures described by Lee et al. (1980) can be used to evaluate available P loads to a particular waterbody.

Withrespect to estimating the amount of organic nitrogen that converts to ammonia/nitrate, it is the authors' experience that organic nitrogen, primarily in the form of algal cells or other recently developed organic-N, will essentially completely convert to algal-available forms over a several-week period. However, aged organic-N can be highly refractory; where only a limited amount will convert to algal-available $\mathrm{N}$.

In developing a eutrophication management program it is important to assess whether nitrogen or phosphorus is limiting or could be made to limit algal growth that impacts the water quality problem of concern. As discussed above, it is important to correctly determine the limiting nutrient through examining whether the concentrations of available nitrogen and phosphorus are growth-rate-limiting during periods of peak algal biomass. If neither is limiting - i.e., both remain surplus at peak biomass - then far greater control of nutrient sources will be needed in order to achieve growth-rate-limiting concentrations, and sufficient reduction beyond that to effect change in eutrophication-related beneficial uses. Figure 4 is a diagrammatic representation of this situation. It is the authors' experience that, typically, excessively fertile waterbodies have nutrient concentrations on the growth rate plateau area in Figure 4. This necessitates a significantly larger - more expansive - nutrient control program than if the excessive fertilization water quality problems occurred in the region of Figure 4 where the growth rate of algae is proportional to nutrient concentrations. While it is relatively easy to control 90 to 95 percent of the phosphorus in typical secondary domestic wastewater discharges through additional wastewater treatment, from the information available in the Chesapeake Bay watershed as well as the lower Great Lakes' watersheds, it appears that it is going to be extremely difficult to control nitrogen and phosphorus from land runoff more than about 40 percent. Sharpley (2000) recently edited a conference proceedings devoted to agricultural phosphorus management in the Chesapeake Bay watershed. He commented that agricultural interests in the Chesapeake Bay are having difficulty meeting a 40 percent reduction in nitrogen and 


\section{Figure 4 -}

\section{Relationship between Nutriont Concentration and Algal Biomass}

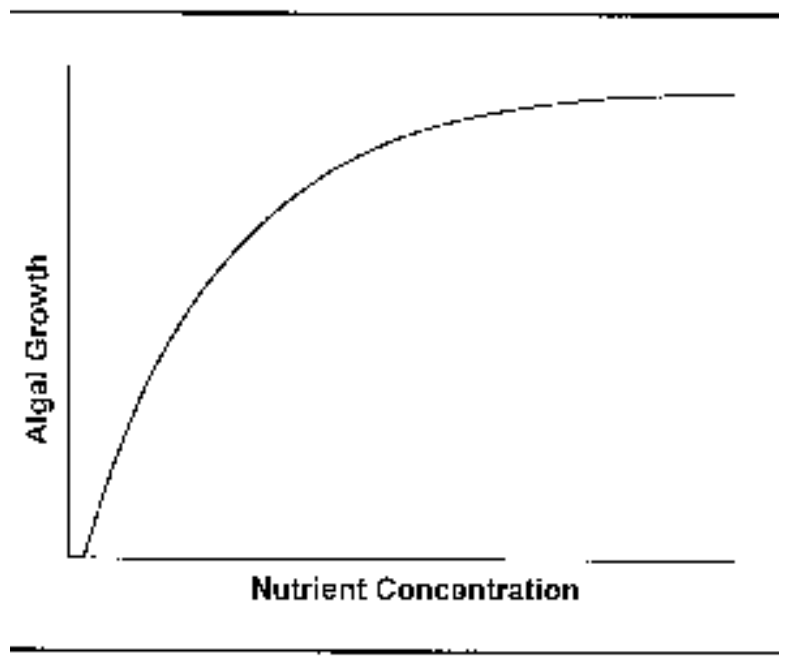

phosphorus loads from land runoff. Logan (2000) discussed similar problems in achieving significant nutrient reductions in the Lake Erie watersheds.

Based on the experience of the Chesapeake Bay and the Lake Erie watersheds, it may be extremely difficult if not impossible to maintain fertilized agricultural production as it is practiced today and also achieve the required nutrient reduction to control the excessive fertilization of some - possibly many waterbodies. It will be important to gain a good understanding of how controlling nitrogen and/or phosphorus added as an inorganic or organic fertilizer/soil amendment willimpact the eutrophication-related water quality of waterbodies of concern.

An important part of developing a technically valid, cost-effective nutrient control program is gaining an understanding of the hydrology and physical limnology/oceanography of the waterbody of concern. It is important to assess whether nutrients added to the waterbody are mixed throughout the waterbody or are present in some parts of the waterbody in higher concentrations than others. There are two types of situations of primary concern, one of these is where the inlet to the waterbody is near the outlet. This type of situation can lead to short- circuiting of nutrients through the waterbody without the opportunity for phytoplankton to fully develop on the added nutrients.

Another issue occurs for long, thin waterbodies, in which nutrients added at one end are not rapidly mixed throughout the waterbody. Under these conditions, it is appropriate to divide the waterbody into plug-flow segments representing about a week to two weeks' travel time per segment, and then determine the amount 
of algal growth that occurs in each segment. The available nutrients removed through algal growth are used to correct the total nutrient load to the waterbody, where this corrected load is that which is to be used in the next plug flow segment. Beron and Lee (1984) described the use of this approach for a reservoir in northern Argentina.

An assessment should be made of the hydraulic residence time (volume divided by annual tributary inflow and precipitation) of the waterbody of concern. If the hydraulic residence time is less than a year then nutrients added during the high flow winter/spring period may be flushed through the waterbody and, therefore, are not available to support the algal growth during the following summer. Under these conditions the nutrient load should be assessed on a monthly basis; the nutrients that contribute to the summer/fall algal growth are the nutrient loads that determine the phytoplankton levels reached during the summer period.

The Vollenweider-OECDeutrophicationmodeling approach is not applicable to very short-residence-time waterbodies. Waterbodies with summer hydraulic residence times of less than about a week to two weeks, do not allow time during the summer for algae to develop to the maximum extent possible based on the nutrient loads to the waterbody. These types of waterbodies would have lower chlorophyll than expected based on its annual normalized P loads (Figure 2).

\section{Developing Nutrient Load-Eutrophication Response Relationship}

A key component of any nutrient control-based program for excessive fertilization management is the development of a nutrient load--eutrophication response relationship for the waterbody of concern. Because of the simplicity of its use and demonstrated reliability for a wide variety of waterbody types located throughout the world, the Vollenweider-OECD eutrophication modeling approach should be evaluated as a potential tool for relating nutrient loads to a waterbody to the planktonic algal growth that develops in the waterbody and guiding the regulation of nutrient input. Using the guidance provided herein and by Jones and Lee (1982a, 1986), the normalized phosphorus load to the waterbody should be evaluated. This load should be used to predict, through Figures 1 and 2, the average planktonic algal chlorophyll that would be expected to be present during the summer. Jones et al. (1979) found that the maximum summer chlorophyll that develops in waterbodies is about 1.7 times the mean summer chlorophyll.

If the planktonic algal chlorophyll found in the waterbody is within the range of values shown in Figure 2 of those previously found in waterbodies throughout the world, then there is reasonable certainty that the Vollenweider-OECD eutrophication modeling approach, using the database developed by Jones and Lee (1982a, 1986), can be used to predict the amount of phosphorus load reduction that needs to be achieved in order to effect the desired waterbody water quality as measured by planktonic algal chlorophyll. If however, there is poor agreement between the measured planktonic algal chlorophyll and the values predicted from the Figure 2 relationship, then either the database upon which the evaluation is being made for the particular waterbody is unreliable, or the application of the Vollenweider-OECD eutrophication modeling approach, is being done incorrectly (e.g., availability of P load, or hydrological and morphological 
characteristics are not properly addressed). It is also possible, although rare, that the particular waterbody of concern is significantly atypical of waterbodies located throughout the world with respect to how an available phosphorus load to the waterbody produces planktonic algalchlorophyll. As noted above, if most of the algal-available phosphorus is used to develop attached algae and/or macrophytes, then the planktonic algal chlorophyll in the waterbody would not be expected to be predicted by Figure 2 .

If there is an insufficient database to reliably assess the normalized phosphorus load and the planktonic algal response to this load, then a relatively simple monitoring program needs to be implemented that will develop the data needed to apply the Vollenweider-OECD eutrophication study results to a particular waterbody. As part of their American Waterworks Association Quality Control and Reservoirs Committee activity, Lee and Jones (1992) developed guidance on the minimum study program that is needed to generate the database for application of the Vollenweider-OECD eutrophication study results to most waterbodies.

\section{Implementing Nutrient Control Programs}

Once the desired level of phosphorus/nitrogen control has been established, then an evaluation needs to be made of the relative significance of various sources of the available nutrient(s) that need to be controlled. It is at this point that an evaluation of the potential role of the water quality significance of any fertilizer (inorganic or organic) including biosolids-derived nutrients that lead to the excessive fertilization of a waterbody, canbe made. It is likely, based on current approaches for nutrient-based TMDL development, that all non-point sources of nutrients will be required to reduce their nutrient export by a specified percentage of the total export from the area.

The work of Gilmour et al. (2000) provided important information on the mineralization of organic nitrogen in biosolids. The approximately 30 percent of the organic nitrogen that is not mineralized during the application growing season as well as the amount of mineralized organic nitrogen and the phosphate, will need to be evaluated with respect to contributing nitrogen and phosphorus in stormwater runoff and agricultural discharges. The Gilmour et al., work needs to be followed up with studies specifically directed toward understanding how nutrients in biosolids, animalmanure, and compost as well as inorganic fertilizers can be applied to land without significant export to surface or groundwaters. Information of this type will be extremely important in determining the loading of inorganic fertilizers and biosolids and other nutrient-rich wastes that can be applied to land without causing surface or groundwater pollution.

\section{Sediments as a Nutrient Source}

There is confusion regarding the importance of hypolimnetic accumulation of nutrients. It is sometimes alleged that the buildup of nutrients in the hypolimnion is an indication of the importance of sediments as a source of nutrients. Ordinarily, the thermocline (density stratification) is an effective barrier for the transport of hypolimnetic nutrients to the surface waters where they can stimulate algal growth. However, there are situations, particularly associated with the sharpening of the thermocline/picnocline as a result of stormdriven mixing of the epilimnion, where nutrients located below the thermocline are transferred into the epilimnion/surface waters. A study of several Wisconsin lakes (Stauffer and Lee, 1973) found that the passage of storm fronts and their associated wind-driven mixing of the epilimnion sharpens the thermocline, 
with the result that some of the waters that had been in the metalimnion region of the thermocline are transferred from the hypolimnion to the epilimnion. In a number of situations, the passage of a storm front resulted in the occurrence of algal blooms about two weeks later, in response to the nutrients derived from the metalimnion/hypolimnion area. Passage of a storm front may also result in the transfer of nutrients at the edge of the thermocline lake edge boundary, where internal waves on the thermocline would break, resulting in mixing of hypolimnetic waters into the epilimnion.

Lee et al. (1977) investigated the importance of oxic versus anoxic release of nutrients in Lake Mendota in Madison, WI. This lake thermally stratifies each summer with the classical hypolimnion nutrient accumulation. They found that the primary source of $\mathrm{N}$ and $\mathrm{P}$ that influenced summer growth of algae was algal mineralization under oxic conditions rather than the anoxic release from the sediments. While under stratified conditions, there can be considerable increase in the $\mathrm{P}$ and $\mathrm{N}$ concentrations in the hypolimnion, except as discussed above, associated with thermocline migration, the thermocline is a fairly effective barrier preventing these nutrients from stimulating the growthofalgae in the euphotic-lighted surface waters.

The fall overturn which mixes the nutrient rich hypolimnetic waters into the water column may not be an important source of phosphorus that is available the next summer to stimulate algal growth. Often associated with fall overturn is the oxidation of ferrous iron that has also accumulated in the hypolimnion under anoxic conditions by the dissolved oxygen introduced into the former hypolimnion at fall overturn. This leads to the formation of ferric hydroxide which can coprecipitate a large amount of the hypolimnetic phosphorus that had accumulated over the stratified period (Lee, 1975 and Lee et al. 1977).

\section{Expected Rates of Recovery}

One of the issues of primary concern in a eutrophication management program based on tributary nutrient input reduction is whether the nutrients in the sediments of the waterbody will represent a significant source of nitrogen and/or phosphorus so as to greatly inhibit the rate of recovery. Sediments of a eutrophic waterbody often contain large amounts of nitrogen and phosphorus in particulate forms. They therefore represent a potential source of nutrients that, until removed from the sediments, could be a significant source that would maintain high levels of algae even though nutrients derived from the watershed have been significantly reduced.

Sonzogni et al. (1976) investigated the rate of recovery of lakes upon reduction of the nutrient input. They found that a phosphorus residence time model best described this rate. The phosphorus residence time of a waterbody is analogous to the hydraulic residence time and is determined by assessing the total mass of phosphorus in the water column divided by the annual P load. The phosphorus residence time of a waterbody is typically much shorter than the hydraulic residence time. For example, for Lake Michigan, the hydraulic residence time is about 100 years, while the phosphorus residence time is about six years. The rate of recovery of a waterbody upon altering phosphorus loads can be estimated as being equal to three times the phosphorus residence time. Sonzogni et al., found that this approach tracked well the rate of recovery for several waterbodies that had experienced reductions in phosphorus input from the watersheds. 
The release of phosphorus from sediments is incorporated into the phosphorus residence time model since the total mass of phosphorus in a waterbody's water column includes the phosphorus released from sediments. The fact that waterbodies recover in accord with phosphorus residence time models demonstrates that the primary source of nutrients for many waterbodies is the watershed, and that while the sediments are a source of nutrients, they are not the dominant source controlling the excessive fertilization of waterbodies. For situations in which nitrogen is the controlling element governing phytoplankton development, nitrogen residence time can also be determined.

The addition of alum (aluminum sulfate) to wastewaters has been found to be an effective approach for removal of phosphorus from the wastewaters. The aluminum hydroxide floc incorporates the phosphorus into the precipitate where it can be removed by sedimentation and/or filtration. Alum has also been used to treat lakes for control of phosphorus. While as discussed by Lee (1971) alum treatment of lakes can be effective in controlling algal blooms, the duration of this effectiveness depends on the hydrologic characteristics of the waterbody. If tributary flow to the waterbody is sufficient to bring a new load of phosphorus to the waterbody in a short period of time, then there will be need to treat the waterbody with alum fairly frequently. If however, the annual load of phosphorus is small compared to the waterbody volume, then alum treatment of a waterbody can be effective for several years.

The phosphorus incorporated into the aluminum hydroxide precipitates is permanently bound within the precipitate. This is different from the situation associated with iron hydroxide precipitation of phosphorus in that under anoxic conditions, the ferric hydroxide is reduced to ferrous iron releasing the phosphorus that was bound in the ferric hydroxide precipitate (Lee et al. 1977).

\section{Phased Nutrient TMDL}

The initialmodeling of eutrophicationresponse to nutrient loads as part of a TMDL nutrient control program is designed to develop the necessary information to formulate a Phase I estimate of the amount of nutrient control needed to achieve a desired eutrophication-related water quality. If the nutrient control program is part of a TMDL, in addition to reducing the nutrient inputs to achieve the desired water quality, it will be necessary to reduce the nutrient loads further to achieve a TMDL-required safety factor. It should be understood that, even with the OECD eutrophication study's modeling approach, there is need to specifically tune the nutrient load-eutrophication response relationships to a particular waterbody.

As shown in Figure 2, there is considerable scatter about the line of best fit for normalized phosphorus loads and average planktonic algal chlorophyll. The deviations represent the individual characteristics of waterbodies that are not accounted for by the Vollenweider normalized phosphorus load modeling approach. In deterministic-type models, in which differential equations are used to describe the various processes, and "range of literature values" are used to determine the coefficients (rate constants) incorporated into these equations, the initial tuning process focuses on adjusting the rate constants until the model results track the existing database for nutrient load, planktonic algal chlorophyll, and Secchi depth. 
However, the fact that deterministic models such as those recommended by the US EPA (1999) are able to be tuned to the existing database does not mean that such models have reliable predictive capability when the nutrient loads are significantly altered from the tuning (rate-constant adjustment) conditions. The differential equations-based approach for modeling environmental processes represents such an oversimplification of the actual processes that govern load-response relationships so as to make the reliability of the modeling of the impact of altered loads on responses questionable in many situations. This lack of a well-defined reliability does not mean that models of these types should not be used. Often, for complex systems, deterministic models which properly describe the hydrodynamics of the system are the only reliable approach that can be used to develop the initial load-response relationship needed for formulating the first phase of a nutrient control program.

The US EPA has adopted a phased approach for TMDL implementation, where the Phase I constituent load is understood to be a rudimentary - sometimes very rudimentary - estimate of the load reductions that will be needed to achieve the desired water quality. The Phase I estimate of loads, coupled with the safety factor, provides a starting point for meaningfully modeling load-response relationships. Phase I of the loadresponse relationship TMDL provides the opportunity to develop the waterbody-specific data for loads and responses to greatly improve the load-response modeling for that waterbody. Detailed, comprehensive monitoring programs of both the loads and the waterbody characteristics during load alteration and final equilibration must be conducted in a meaningful Phase I program. This information then is used to adjust the allowable loads to achieve the desired water quality in Phase II.

Phase II should be developed if the desired water quality is not achieved in Phase I. Because of year-toyear climate-related variability in nutrient load-eutrophication response relationships for waterbodies, it is recommended that at least three, and preferably five, years of Phase I monitoring be conducted after the nutrient load reductions have been substantially completely implemented and the waterbody has adjusted to the new nutrient loads. This adjustment period is estimated as three times the limiting-nutrient residence time for the waterbody. Therefore, since it is likely to take several years after a TMDL load allocationhas been developed before the nutrient control programs are in place and operating reliably, ultimately, Phase II in the nutrient control eutrophication response management program may not be implemented until at least five, and sometimes ten or more, years after the TMDL and its allocations have been developed/agreed to. Since, in many TMDL situations, it is possible that there will be litigation involving stakeholders' objecting to the load reduction allocation provided them, this could delay the initiation of Phase II of the TMDL implementation from five to 15 years after the TMDL is first formulated and allocated.

\section{Nutrient Load Reduction Allocation}

The allocation of allowable nutrient loads among the dischargers can be assigned based on respective responsibilities, where each discharger is required to reduce its load by a certain amount of its share of the total load. However, economic, political, and legal issues can often influence the allowed nutrient discharges from the various sources. Basically, nutrient load reduction allocation is a societal process whereby society can decide which of the dischargers of nutrients or others who influence how the nutrients 
impact water quality, should financially support nutrient control. For example, it may be appropriate to require domestic wastewater treatment plants to remove 90 to 95 percent of the phosphorus, which can typically be done at a cost of a few cents per person per day for the population served by the treatment plant, and to require 30 to 50 percent control of phosphorus from agricultural land runoff/discharges.

Another area that is receiving increasing attention is pollutant load trading, whereby one type of discharger will remove a greater percentage of nutrients than other dischargers. Rather than a municipality spending large amounts of money to remove the last percent or so of a nutrient from the wastewater discharges, the municipality may find that it is more cost-effective to help support (fund) agricultural interests to remove nutrients.

One of the aspects of nutrient control from agricultural lands that must be considered is that removing a substantial part of the nutrients from agricultural runoff/discharges may be cost-prohibitive in terms of maintaining a viable agriculture. For many crops, the profit margin for average-year production is small, leaving limited ability to spend funds on nutrient removal without jeopardizing the overall economic viability of the agricultural enterprise. Since maintaining viable agriculture in a region may be considered societally desirable, it may be determined that the urban nutrient discharges through wastewaters and stormwater runoff should remove a greater proportion of nutrients from these discharges than required fromagricultural lands.

It is extremely important that pollutant trading programs be based on available forms of nutrients, and not total nutrients, which include large amounts of unavailable nutrients. Numerous technically invalid pollutant trading programs that have been developed, which incorporate trades of discharge of unavailable nutrients for discharge of available nutrients. Both the Lake Dillon Reservoir near Denver, Colorado, and the North Carolina Pamlico River estuary phosphorus control programs were based on total phosphorus, rather than algal-available phosphorus. This can lead to an inappropriate pollutant (phosphorus) trading program (Lee and Jones-Lee, 1994).

Another aspect of pollutant trading is the examination of both near-field impacts of nutrients (i.e., near the point of discharge), as well as the far-field (downgradient or waterbody-wide) effects. Nutrients discharged into bays or arms of a larger waterbody can readily have a significant adverse effect in the bay, but not in the waterbody overall. The bay adverse effects near the point of discharge could be severe and require greater nutrient control than if the issue were bay-wide impacts. Lee and Jones-Lee (1996) have discussed the importance of critically reviewing the impacts of nutrients for both near-field and far-field situations in the development of TMDL goals.

In the San Joaquin River Deep Water Ship Channel watershed, a number of municipalities are prohibited from discharging domestic wastewaters to the SanJoaquin River because of adverse impacts on river water quality during the summer and fall. These municipalities discharge their wastewaters to land during the summer/fall. There is concern, however, about whether this land disposal of wastewaters during this period could lead to contamination of shallow groundwater by nitrate, which in turn, through discharge to the 
surface waters, could be an important source of nitrate for the San Joaquin River. It is important in any land application of wastewaters to be certain that such an approach does not result in pollution of shallow groundwater that then transports the nutrients to surface waters.

In some instances, responsibility for eutrophication-related water quality problems may lie to a considerable extent with non-nutrient dischargers. An example of this type of situation occurs in the development of nutrient control programs for the San Joaquin River Deep Water Ship Channel. As discussed by Lee and Jones-Lee (2000a), algae that develop within the San Joaquin River watershed, as well as within the channel, are a major cause of the dissolved oxygen depletion to levels below the water quality objectives, that occurs each summer and fall. The San Joaquin River upstream of the Deep Water Ship Channel is about ten feet deep. It discharges to a ship channel that is 35 feet deep. This increased depth and its associated volume greatly changes the hydraulic residence time of the water and, therefore, the exertion of the oxygen demand associated with the algae that are brought into the ship channel from upstream sources.

Since the San Joaquin River does not have DO depletions below water quality standards upstream of the ship channel, it can be argued that the Port of Stockton (the Port for which the channel was developed) and those who benefit from the Port activities have a responsibility for causing the DO depletion within the channel; without the channel, there would be no significant DO depletion problems. These issues are being discussed by the San Joaquin River DO TMDL Steering Committee, where DO depletion below water quality objectives arising from the existence of the channel, is being assigned a responsibility factor that is equivalent to a load of oxygen demand.

Another factor that is important in the oxygen demand of the San Joaquin River Deep Water Ship Channel is the fact that, at times, through water diversions primarily for export to Central and Southern California, there is little flow through the channel. This results in a situation where the hydraulic residence time of the channel changes from about a week to as muchas four weeks. Under these conditions, an oxygen demand load that would be acceptable under higher flow conditions may cause severe DO depletion below the water quality standard under low-flow conditions. Here again, the diversion of water by those who manipulate flows through and around the channel carries with it a responsibility for DO depletion. If the flows were maintained through the channel, the amount of oxygen demand that oxygen-demand dischargers would have to remove could be considerably less than that which will be required under lower flow conditions. The San Joaquin River DO TMDL Steering Committee is exploring ways to assign a responsibility for DO depletion to those who divert flows out of the channel and thereby increase the DO depletion and the residual oxygen demand loads brought into the channel.

One of the approaches that is being explored for control of DO depletion within the Deep Water Ship Channel is aeration of the channel. It may be far more cost-effective for the dischargers of oxygen demand and nutrients that cause the DO depletion within the channel to pay for aeration, rather than to try to treat the runoff from agricultural lands which contribute nutrients that lead to algae which cause oxygen depletion in the channel. It is possible that, through financial support from the water diverters and the Port of 
Stockton - those who benefit from the Port and agricultural and domestic wastewater interests - the cost of aeration could be shared among dischargers and those who adversely impact how an oxygen demand load/algae impact DO depletion within the channel. It will be interesting to see how the allocation/funding of nutrient control finally evolves in the San Joaquin River Deep Water Ship ChannelTMDL, withparticular reference to assigning responsibility to the Port and the water diverters, where they would have an assigned responsibility for helping to pay for correcting the problem of low DO due to the decay of algae within the channel.

The San Joaquin River DO TMDL development efforts face a somewhat unusual situation for surface waters, with respect to establishing the TMDL goal to eliminate violations of water quality standards for dissolved oxygen within the water column. One of the important issues that must be resolved in developing this TMDL is whether the DO water quality standard is to be implemented as a worst-case value, not to be exceeded at any time or location. The US EPA national water quality criterion for dissolved oxygen is $5 \mathrm{mg} / \mathrm{L}$. The Agency, however, does not have a policy on whether this $5 \mathrm{mg} / \mathrm{L}$ is an average considering the diel DO changes associated with photosynthesis and respirationinthe near-surface waters or in the DO depletion that can occur near the sediment/water interface due to sediment oxygen demand.

A significantly different reduction in nutrient loads to a waterbody can have to occur if the DO water quality standard is implemented as a worst-case value, not to be exceeded by any amount more than once every three years (i.e., typical Clean Water Act water quality standards implementation approach used by the US EPA) or can be an average value for the water column, largely ignoring the DO depletion that occurs in the early morning hours due to algaland bacterial respiration and near the sediment/water interface during times of limited mixing of the waters in the water column down to the sediments.

\section{CONCLUSIONS}

All sources of nitrogen and phosphorus that are discharged to waterbodies that are experiencing excessive fertilization - which include many inland waterbodies and much of the East coast, the Gulf coast, and some of the West coast near-shore marine waters - will be subject to increased scrutiny as part of TMDL efforts to control excessive nitrogen and/or phosphorus inputs to the waterbodies. All sources of nutrients (inorganic and organic fertilizers) will likely receive increased scrutiny as a contributor to excessive fertilization of waterbodies. It will be important for all managers of sources of nutrients, and especially biosolids, to develop and then actively participate in monitoring programs to define, on a waterbody/watershed-specific basis, the role that a particular nutrient source plays in impacting the excessive fertilization of the receiving waters for stormwater runoff and irrigation water discharges. It will also be important to reliably evaluate how the eutrophication-related water qualityproblems associated with a particular nutrient source and type of nutrient source, impact excessive fertility of a waterbody and in particular, how reduction of that nutrient source will impact the eutrophication-related water quality problems of the waterbody. 


\section{REFERENCES}

Many of the papers and reports developed by the authors and cited herein are available from the authors' website,www.gfredlee.com, or directly from them upon request, at gfredlee@aol.com.

Ambrose, R. B.; T. A. Wool; J. P. Connolly and R. W. Schanz, WASP4, a hydrodynamic and water quality model: Model theory, user's manual and programmers guide, EPA/600/3-87/039, U.S. Environmental Protection Agency, Envir. Research Laboratory, Athens, GA (1988).

Ambrose, R. B.; Wool, T. A. and Martin, J. L., The water quality analysis simulation program, WASP5, Part A: Model documentation, Version 5.10, United States Environmental Protection Agency, Environmental Research Laboratory, Athens, GA (1993a).

Ambrose, R. B.; Wool, T. A. and Martin, J. L., The water quality analysis simulation program, WASP5, Part B: The WASP5 input dataset, Version 5.10, United States Environmental Protection Agency, Environmental Research Laboratory, Athens, GA (1993b).

Archibald, E. M. and Lee, G. F., "Application of the OECD Eutrophication Modeling Approach to Lake Ray Hubbard, Texas,” J. Am. Water Works Assoc. 73:590-599 (1981).

Beron, L. E. and Lee, G. F., "Aplicacion Preliminar de un Modelo de Eutrofication al Embalse de Salto Grande,” Proc. de Cong. Interamer. de Ingen. Sanit. y Ambie. 2, Santiago-Chile, (1984).

Bowie, G. L.; Mills, W. B.; Porcella, D. B.; Campbell, C. L.; Pagenkopf, J. R.; Rupp, G. L.; Johnson, K. M.; Chan, P. W. H.; Gherini, S.A. and Chamberlin, C.E., "Rates, Constants, and Kinetics Formulations in Surface Water Quality Modeling, 2nd Ed.," US Environmental Protection Agency, Envir. Research Laboratory, EPA/600/3-85/040, Athens, GA, June (1985).

Fitzgerald, G. P., "The Effect of Algae on BOD Measurements,” J. Wat. Pollut. Control Fed. 36:1524 (1964).

George, D. B.; Leftwich, D. B. and Klein, N. A., "The Lubbock Land Treatment System Research and Demonstration Project," US Environmental Protection Agency, EPA/600/2-86/27a (1986).

Gilmour, John T.; Cogger, C.; Jacobs, L. W.; Wilson, S. A.; Evanylo, G. K. and Sullivan, D. M., "Nitrogen Management Protocols for Biosolids Beneficial Use," Project 97-REM-3, Water Environment Research Foundation, Alexandria, VA (2000).

Jones, R. A. and Lee, G. F., "Septic Tank Wastewater Disposal Systems as Phosphorus Sources for Surface Water,” Journ. Water Pollut. Control Fed., 51:2764-2775 (1979).

Jones, R. A. and Lee, G. F., "Recent Advances in Assessing the Impact of Phosphorus Loads on Eutrophication-Related Water Quality," Journ. Water Research, 16:503-515 (1982a). 
Jones, R. A. and Lee, G. F., "Chlorophyll - A Raw Water Quality Parameter," J. Am. Water Works Assoc., 74:490-494 (1982b).

Jones, R. A. and Lee, G. F., "Eutrophication Modeling for Water Quality Management: An Update of the Vollenweider-OECD Model,’World Health Organization's Water Quality Bulletin 11(2):67-174, 118 (1986).

Jones, R. A., and Lee, G. F., "Use of Vollenweider-OECD Modeling to Evaluate Aquatic Ecosystem Functioning," In: Functional Testing of Aquatic Biota for Estimating Hazards of Chemicals, ASTM STP 988, American Society for Testing Materials, Philadelphia, PA. pp 17-27 (1988).

Jones-Lee, A. and Lee, G. F., "The Relationship Between Phosphorus Load and EutrophicationResponse in Lake Vanda," Physical and Biogeochemical Processes in Antarctic Lakes, 59:197-214, American Geophysical Union, Washington, DC (1993).

Jones, R. A.; Rast, W. and Lee, G. F., "Relationship between Mean and Maximum Chlorophyll A Concentrations in Lakes," Environ. Sci. \& Technol. 13:869-870 (1979).

Lee, G. F., "Factors Affecting the Transfer of Materials between Water and Sediments," Univ. of Wisconsin Eutrophication Information Program, Literature Review No. 1, 50 pp (1970).

Lee, G. F., "Eutrophication,” Encyclo. of Chem. Tech., John Wiley \& Sons, pp 315-338 (1971).

Lee, G. F., "Role of Hydrous Metal Oxides in the Transport of Heavy Metals in the Environment," Proc. Symposium on Transport of Heavy Metals in the Environment, Progress in Water Technology. 17:137147 (1975).

Lee., G. F., "Development of a TMDL for Oxygen Demand Constituents in the San Joaquin River Deep Water Ship Channel,” North American Lake Management, December (1999).

Lee, G. F. and Jones, R. A., "Application of the OECD Eutrophication Modeling Approach to Estuaries," IN: Estuaries and Nutrients, Humana Press, Clifton, NJ, pp 549-568 (1981).

Lee, G. F. and Jones, R. A., "Detergent Phosphate Bans and Eutrophication,” Environ. Sci. \& Technol., 20(4):330-331 (1986).

Lee, G. F. and Jones, R. A., "The North American Experience in Eutrophication Control through Phosphorus Management," in Proc. Int. Conf. Phosphate, Water and Quality of Life, Paris, France (1988). 
Lee, G. F. and Jones, R. A., "New Jersey's Coastal Water Quality: An Overview," New Jersey Effluents 23:11-17, 25 (1989).

Lee, G. F. and Jones, R. A., "Regulating Drinking Water Quality at the Source," Proc. University of California Water Resources Center Conference: "Protecting Water Supply Water Quality at the Source," Sacramento, CA, 39pp, April (1991). Publ. in proc. as: Lee, G. F. and Jones, R. A., "Managing Delta Algal Related Drinking Water Quality: Tastes and Odors and THM Precursors," pp. 105-121, April (1991a).

Lee, G. F. and Jones, R. A., "Effects of Eutrophication on Fisheries," Reviews in Aquatic Sciences, 5:287-305, CRC Press, Boca Raton, FL (1991b).

Lee, G. F. and Jones, R. A., "Study Program for Development of Information for Use of Vollenweider-OECDEutrophication Modeling in Water Quality Management for Lakes and Reservoirs," Report of G. Fred Lee \& Associates, El Macero, CA, 22pp, (1992).

Lee, G. F. and Jones-Lee, A., "Valid Pollutant Credit Trading," Water Envir. \& Tech., ㅁ:10 (1994).

Lee, G. F. and Jones-Lee, A., "Mechanisms of the Deoxygenation of the Hypoliminia of Lakes," Report of G. Fred Lee \& Associates, El Macero, CA (1995).

Lee, G. F. and Jones-Lee, A., "Water Quality Issues in Pollutant Trading," Report of G. Fred Lee \& Associates, El Macero, CA, February (1996).

Lee, G. F. and Jones-Lee, A., "Determination of Nutrient Limiting Maximum Algal Biomass in Waterbodies," G. Fred Lee \& Associates, El Macero, CA (1998a).

Lee, G. F. and Jones-Lee, A, "Comments on 'National Strategy for the Development of Regional Nutrient Criteria' Developed by the US EPA Office of Water, June 1998," Submitted to the US EPA, Washington, D.C., August (1998b).

Lee, G. F. and Jones-Lee, A., "Issues in Developing the San Joaquin River Deep Water Ship Channel DO TMDL," Report to Central Valley Regional Water Quality Board, August (2000a).

Lee, G. F. and Jones-Lee, A., "TMDL Development to Control DO Depletion in the San Joaquin River Deep Water Ship Channel," CALFED Science Conf., Sacramento, CA, October (2000b).

Lee, G. F.; Jones-Lee, A. and Rast, W., "Alternative Approaches for Trophic State Classification for Water Quality Management, Part I: Suitability of Existing Trophic State Classification Systems," Report of G. Fred Lee \& Associates, El Macero, CA (1995a). 
Lee, G. F.; Jones-Lee, A. and Rast, W., “Alternative Approaches for Trophic State Classification for Water Quality Management, Part II: Application of Vollenweider-OECD Eutrophication Modeling Approach," Report of G. Fred Lee \& Associates, El Macero, CA (1995b).

Lee, G. F.; Jones-Lee, A., and Rast, W., "Secchi Depth as a Water Quality Parameter," Report of G. Fred Lee \& Associates, El Macero, CA (1995c).

Lee, G. F.; Jones, R. A. and Rast, W., “Availability of Phosphorus to Phytoplankton and its Implication for Phosphorus Management Strategies," In: Phosphorus Management Strategies for Lakes, Ann Arbor Press, Ann Arbor, MI, pp 259-308 (1980).

Lee, G. F.; Rast, W. and Jones, R. A., "Eutrophication of Waterbodies: Insights for an Age-Old Problem," Environ. Sci. \& Technol., 12:900-908 (1978).

Lee, G. F.; Rast, W.; Jones, R. A. and Ortiz, J. L., "Progresos Recientes en la Estimacion de la Respuesta de los Lagos y Embalses a Las Aportacioines de Nutrientes,"Centro De Estudios Hidrograficos, Ministerio de Orbas Publicas y Urbanismo, Publication Numero 137 (1980).

Lee, G. F.; Sonzogni, W. C. and Spear, R. D., "Significance of Oxic versus Anoxic Conditions for Lake Mendota Sediment Phosphorus Release," Proc. Int. Symp. on Interactions between Sediments and Fresh Water, Amsterdam, 1976, W. Junk, Purdoc, The Hague, pp 294-306 (1977).

Logan, T., "Nonpoint Sources of Pollutants to the Great Lakes: 20 Years Post PLUARG," In: Nonpoint Sources of Pollution to the Great Lakes Basin, Great Lakes Science AdvisoryBoard, International Joint Commission Workshop Proceedings, February (2000).

OECD, "Eutrophication of Waters, Monitoring, Assessment, and Control," Organization for Economic Cooperation and Development, Paris (1982).

Ortiz, J. L.; Lee, G. F. and Jones, R. A., "Development of Basis for Establishing Eutrophication Management Program for Spanish Impoundments," Proc. ISCHIA Symposium on Surface Water Impoundments, ISCHIA, NY, pp 435-446 (1981).

Rast, W.; Jones, R. A. and Lee, G. F., 'Predictive Capability of US OECD Phosphorus LoadingEutrophication Response Models,” Journ. Water Pollut. Control Fed., 55:990-1003 (1983).

Rast, W. and Lee, G. F., "Summary Analysis of the North American (US Portion) OECD Eutrophication Project: Nutrient Loading-Lake Response Relationships and Trophic State Indices," US Environmental Protection Agency, EPA 600/3-78-008, Corvallis, OR (1978).

Rast, W. and Lee, G. F., “Nutrient Loading Estimates for Lakes,” J. Env. Eng., 109:502-517 (1983). 
Sharpley, A. N., (ed), Agricultural and Phosphorus Management - The Chesapeake Bay, CRC Press, Boca Raton, FL (2000).

Sonzogni, W. C.; Uttormark, P. C. and Lee, G. F., "A Phosphorus Residence Time Model: Theory and Application," Water Res. 10:439-435 (1976).

Stauffer, R. E. and Lee, G. F., "The Role of Thermocline Migration in Regulating Algal Blooms," Proc. Workshop Modeling the Eutrophication Process, Utah State Univ. 73-82 (1973).

US EPA, “Ambient Water Quality Criteria for Dissolved Oxygen,” US Environmental Protection Agency, Office of Water, EPA 440/5-86-003 (1986).

US EPA, “Quality Criteria for Water 1986," US Environmental Protection Agency, Office of Water, EPA 440/5-86-001 (1987).

US EPA, "Technical Guidance Manualfor Developing Total Maximum Daily Loads; Book 2: Streams and Rivers; Part 1: Biochemical Oxygen Demand/Dissolved Oxygen and Nutrients/Eutrophication," US Environmental Protection Agency, EPA 823-B-97-002, (1997).

US EPA, "National Strategy for the Development of Regional Nutrient Criteria", US Environmental Protection Agency, Office of Water, EPA 822-R-98-002 (1998).

US EPA, "Protocol for Developing Nutrient TMDLs," US Environmental Protection Agency, Office of Water, EPA 841-B-99-007 (1999).

US EPA, "Nutrient Criteria Technical Guidance Manual, Lakes and Reservoirs," US Environmental Protection Agency, Office of Water, EPA-822-B00-001 (2000a).

US EPA, "National Water Quality Inventory," US Environmental Protection Agency, Office of Water, EPA841-R-00-001 (2000b).

Vollenweider, R. A., "The Scientific Basis of Lake and Stream Eutrophication with Particular Reference to Phosphorus and Nitrogen as EutrophicationFactors," Technical Report DAS/DS1/68.27, Organization for Econ. Cooperation and Development, Paris, France (1968).

Vollenweider, R. A., "Input-Output Models with Special Reference to the Phosphorus Loading Concept in Limnology," Schweiz. Zeitschr., Hydrol., 37:53-84 (1975).

Vollenweider, R. A., "Advances in Defining Critical Loading Levels for Phosphorus in Lake

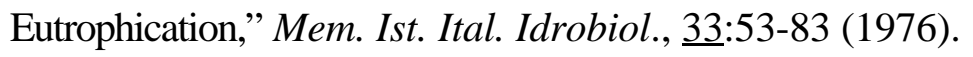


Vollenweider, R. A. and Kerekes, J. J., "Background and Summary Results of the OECD Cooperative Program on Eutrophication," In: Proceedings of an International Symposium on Inland Waters and Lake Restoration, pp. 26-36. US Environmental Protection Agency, EPA 440/5-81-010 (1980). 